\title{
Cross-cultural adaptation and validation of the PRISMA-7 scale for European Portuguese
}

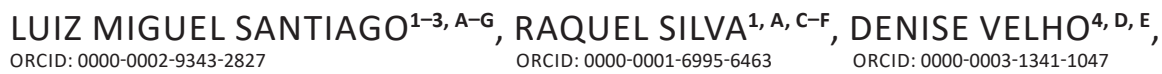 \\ ORCID: 0000-0003-1341-1047 \\ INÊS ROSENDO1, 2, 5, D-G, JOSÉ AUGUSTO SIMÕES², 4, 5, D-G \\ ORCID: 0000-0001-8838-6021 ORCID: 0000-0003-2264-7086 \\ ${ }^{1}$ Faculty of Medicine, University of Coimbra, Portugal \\ ${ }^{2}$ University Clinic of General and Family Medicine, Faculty of Medicine, University of Coimbra, Portugal \\ ${ }^{3}$ CEISUC - Centre for Health Studies and Investigation of the University of Coimbra, Portugal \\ ${ }^{4}$ Faculty of Health Sciences, University of Beira Interior, Covilhã, Portugal \\ ${ }^{5}$ CINTESIS - Centre for Research in Health Technologies and Service, Porto, Portugal
}

A - Study Design, B - Data Collection, C - Statistical Analysis, D - Data Interpretation, E - Manuscript Preparation, F - Literature Search, G - Funds Collection

Summary Background. Frailty is an age-associated biological syndrome and a predictor of multimorbidity outcomes, whose early recognition allows for the identification of those older patients at risk. The PRISMA-7 scale allows for the identification of frail older people. Objectives. To make a cross-cultural adaptation and validation of the PRISMA-7 to the European spoken Portuguese language.

Material and methods. Cross-cultural adaptation by translation of the PRISMA-7 scale into European Portuguese, debriefing and back-translation to English. Application for intra-observer reliability assessment and validation by simultaneous and concurrent application of the Katz scale.

Results. Cronbach's alpha coefficient was of 0.420 and 0.409 after a re-test. Spearman's Rank Order Correlation of 0.969 in the re-test operation in a sample of 64 older people ( 35 female). More than 3 affirmative answers were found for older people $(p<0.001)$, for a higher number of self-reported drugs taken, $(p=0.001)$, self-reported years of education $(p=0.001)$, higher values for those with less years of studies were found in the validation of the translated PRISMA-7 scale, in a purposive sample of 127 older people, 72 (56.7\%) female. No differences were found between gender $(p=0.414)$ and for number of self-reported diseases $(p=0.258)$. A Spearman correlation of $\rho=0.477(p<0.001)$ between the total of the two scales was found.

Discussion. This comprehensive tool enables health care providers to discuss and architect more effective and efficient measures for these patients' care, regardless of gender, socio-demographic factors, number of self-reported drugs taken and diseases.

Conclusions. The PRISMA-7 scale is now recommended to identify frail older people in the Portuguese community. Key words: frailty, frail elderly, disease susceptibility, general practice.

Santiago LM, Silva R, Velho D, Rosendo I, Simões JA. Cross-cultural adaptation and validation of the PRISMA-7 scale for European Portuguese. Fam Med Prim Care Rev 2020; 22(1): 59-66, doi: https://doi.org/10.5114/fmpcr.2020.92507.

\section{Background}

The ageing population poses new challenges for health and social care services [1-6]. The increase in life expectancy is inversely associated with healthy life expectancy, implying a longer lifespan with disability and, therefore, increased use of health care, multimorbidity and frailty $[2,7]$. The group of frail older people is increasing due to ageing and an increase in life expectancy [6]. A high percentage of emergency patients are frail older patients, and they are the fastest growing group in primary care $[6,8,9]$.

Frailty is an age-associated biological syndrome with multisystem down-dysregulation, reduced physiological reserves [7-11] and capacity to maintain homeostasis [1, 12-17], loss of cognitive function [18], functional decline $[5,6]$, increased risk of being institutionalised [19] and vulnerability to stressors [9-11, 13-15, 20], risk of falls, disability, dependence [4, 18], activity limitations, imminent death, hospitalisation, prolonged recovery and relapse $[1,8,16,19,21-25]$. Frail older patients present a long clinical course of disease with intermittent episodes of decline and experiencing a lack of coping strategies when dealing with change and disruptions $[2,19]$. Very old patients evaluate their health problems based on impact [26].
Interactions between physiological changes due to ageing, polypharmacy, multimorbidity and functional impairment are often complex [21].

Frailty is more prevalent in developing countries and is associated with socio-demographic variables, such as gender and age [14]. The incidence of frailty increases with age, lower education and income, poor health, multimorbidity and disability and is higher in women and in Afro-Americans [11].

A high percentage of frail older patients suffering from multimorbidity and recurrent acute illnesses is treated in specialised acute care units $[5,6,8,21]$. After discharge, older patients have a higher risk of mortality, and approximately one-third of older patients experience a loss of independence in self-care activities, including personal and instrumental activities of daily living, which are related with poor nutrition, loss of sphincter control, and decreased self-care and low mobility during hospitalisation $[18,21]$. Functional decline is associated with worse outcomes of health-related quality of life, less living at home, more re-hospitalisations and higher health costs, which result in the use of more expensive and intensive services and higher mortality $[18,21,27]$.

Frailty is a predictor and an outcome of multimorbidity needing to be diagnosed early $[1,23]$. Functional status assess- 
ment in geriatric practice is important for early diagnosis, as it has implications in prognosis, as well as in optimising care, planning interventions and preventing the progression of frailty [17, $18,23,28]$.

Several frailty instruments evaluate weakness, slowness, low physical activity, unintentional weight loss, accumulation of deficits and exhaustion, which are aspects of the clinical phenotype of frailty that should be diagnosed with no delay [8-10, 13, $14,16,21-24,27]$.

Comprehensive geriatric assessment, treatment and rehabilitation is associated with decreased mortality, less functional decline at discharge, reduced care needs and a higher probability of living at home $[3,5,8,13,21]$. Thus, to adequately prevent hospitalisation, we need to study ambulatory older people with an adequate instrument to prevent delay of functional decline [29].

The Program on Research for Integrating Services for the Maintenance of Autonomy (PRISMA) was developed in Canada in 2005 [29]. The PRISMA model includes the PRISMA-7 questionnaire, validated to screen for frailty, which allows services to be adapted to clients' needs [29, 30]. PRISMA-7 identifies risk factors for functional decline through seven dichotomous items $[29,31]$.

In the Canadian study, PRISMA-7 had $78 \%$ sensitivity and $75 \%$ specificity with a cut-off point of three or more positive answers for identification of functional decline in older patients, and $61 \%$ sensitivity and $91 \%$ specificity with a cut-off point of four or more positive answers [30]. Due to the good performance of PRISMA-7 in comparison with other frailty assessment instruments, the Royal College of General Practitioners and the British Geriatrics Society recommend PRISMA-7 for frailty identification [29, 31].

The Katz scale is an index of independence in daily life activities, developed by Sidney Katz, and is one of the mostly used instruments in geriatric evaluation [32]. The scale measures hierarchically related activities of daily living and allows for the evaluation of independence in the execution of six daily life functions [32]. The Katz scale allows for the monitoring of the evolution of disability through ageing, as well as of the prognosis, intervention planning and evaluation of the effectiveness of performed treatments [32].

Daily life activities are influenced by one's culture and are determined by behaviour, cultural norms and values, making cross-cultural validation of scales important in research [28].

\section{Objectives}

This study aims to make the cross-cultural adaptation and validation of the PRISMA-7 scale, assessing its psychometric properties concurrently with another well-known health related scale, the Katz scale.

\section{Material and methods}

The study was made in accordance to an health ethics commitee aproved protocol.

According to the "Program of Research to Integrate Services for the Maintenance of Autonomy (PRISMA)" being over 85 years, being a male, suffering from health limiting problems, needing regular help for daily activities or being restricted at home, needing help to move around or to perform daily hygiene are factors to punctuate in a dichotomous instrument, valuing more than three positive answers as frailty. The scale is shown in Table 1.

The study's first phase was the cross-cultural adaptation to Portuguese language of the PRISMA-7 scale, which was then backtranslated from English [30] to European Portuguese. The original English scale consists of seven dichotomous questions, since the intended answer is a yes or no response, as shown in Table 1.

The translation was made by two people, fluent in technical English language, whose mother tongue is Portuguese. This translation was then retranslated into English by a bilingual Portuguese/English teacher, who did not have any information about the concepts and objectives of the questionnaire. The purpose of the retranslation was to verify the popular use of the source language and to correct any ambiguous meanings of the original questionnaire. A debriefing was then undertaken by three medical doctors to verify the compatibility of the Portuguese wording to the English original.

\begin{tabular}{|l|l|}
\hline \multicolumn{2}{|l|}{ Table 1. PRISMA-7 original English version [30] } \\
\hline Questions & $\begin{array}{l}\text { Answer } \\
\text { Yes No }\end{array}$ \\
\hline P1: Are you older than 85 years? & $\square \quad \square$ \\
P2: Are you male? & $\square \quad \square$ \\
P3: In general, do you have any health problems & \\
that require you to limit your activities? & $\square \quad \square$ \\
P4: Do you need someone to help you regularly? & $\square \quad \square$ \\
P5: In general, do you have any health problems \\
that require you to stay at home? \\
P6: If you need help, can you count on someone \\
close to you? \\
P7: Do you regularly use a cane, a walker, or \\
a wheelchair to move about? \\
\hline
\end{tabular}

Subsequently, in the second phase of the study, the Portuguese version of the PRISMA-7 scale was applied in two different moments to evaluate the scale's intra-observer reliability (test/ /re-test). An epidemiological scale was simultaneously applied in the first moment. Both scales were self-administered, with a guarantee of anonymity and confidentiality after informed consent to persons older than 64 years, of whom 35 were female, selected from the ambulatory care on the island of São Miguel, Azores, and in Portugal central mainland in the city of Coimbra. For test/re-test reliability analysis, Chronbach's alpha coefficient was used, and Spearman's Rank Order Correlation was used to calculate the strength of the relationship between the results obtained in the two different moments. The Mann-Whitney $U$ Test was used to test differences between the results obtained in the two different moments, and the chi-square test for Independence was used to explore the relationship between socio-demographic variables [33]. We also performed a study on the level of literacy and the perceptibility of the scale.

The study's third phase aimed to validate the PRISMA-7 scale with the Katz scale. The questionnaire was applied to 127 older people in the same health units. Simultaneously, an epidemiological scale was also self-administered, guaranteeing anonymity and confidentiality after informed consent. For analysis of the results, the Mann-Whitney $U$ Test was used to test for differences between socio-demographic variables and the number of affirmative answers on the PRISMA-7 scale, Pearson's correlation was used to explore the strength of the relationship between PRISMA-7 and the Katz scale, and the chi-square test for Independence was used to explore the relationship between sociodemographic variables. A $p<0.001$ value was used to address statistical difference [33], and a cut-off value of three affirmative answers was defined for study use. The presence of three or more affirmative answers will allow for the diagnosis of frailty.

\section{Results}

Study phase 1: The cross-cultural adaptation to Portuguese was made according to the methodology previously described and ended with the results shown in Table 2.

Study phase 2: Table 3 shows the socio-demographic characteristics of the purposive phase 2 sample of 64 older people, of whom 35 (54.7\%) were female. Women were older than men, reported more simultaneous diseases and medications and had less years of education. These last three items showed a statistical difference. 


\begin{tabular}{|l|l|}
\hline Table 2. Translation of PRIMA 7 into Portuguese spoken in Europe & \\
\hline Questões & $\begin{array}{l}\text { Resposta } \\
\text { Sim Não }\end{array}$ \\
\hline Tem mais de 85 anos? & $\square$ \\
É do sexo masculino? & $\square$ \\
Em geral, tem algum problema de saúde que o/a obrigue a diminuir ou limitar as suas atividades? & $\square$ \\
Precisa da ajuda de alguém regularmente? & $\square$ \\
Em geral, tem algum problema de saúde que o/a obrigue a ficar em casa? & $\square$ \\
Se precisar de ajuda, tem alguém próximo para o/a ajudar? & $\square$ \\
Utiliza regularmente bengala, andarilho ou cadeira de rodas? & $\square$ \\
\hline
\end{tabular}

\begin{tabular}{|c|c|c|c|c|c|}
\hline & & & \multicolumn{2}{|l|}{ Gender } & \multirow[t]{2}{*}{ Total } \\
\hline & & & male & female & \\
\hline \multirow{6}{*}{$\begin{array}{l}\text { Age } \\
p=0.127\end{array}$} & \multirow[t]{2}{*}{$65-75$ years } & count & 15 & 12 & 27 \\
\hline & & gender \% & $51.7 \%$ & $34.3 \%$ & $42.2 \%$ \\
\hline & \multirow[t]{2}{*}{$76-85$ years } & count & 3 & 3 & 6 \\
\hline & & gender $\%$ & $10.3 \%$ & $8.6 \%$ & $9.4 \%$ \\
\hline & \multirow{2}{*}{$\begin{array}{l}\text { equal or greater } \\
\text { than } 86 \text { years }\end{array}$} & count & 11 & 20 & 31 \\
\hline & & gender $\%$ & $37.9 \%$ & $57.1 \%$ & $48.4 \%$ \\
\hline \multirow{8}{*}{$\begin{array}{l}\text { Number of self-reported } \\
\text { diseases } \\
p<0.001\end{array}$} & \multirow[t]{2}{*}{ up to 2 diseases } & count & 21 & 11 & 32 \\
\hline & & gender $\%$ & $72.4 \%$ & $31.4 \%$ & $50.0 \%$ \\
\hline & \multirow[t]{2}{*}{3 to 4 diseases } & count & 6 & 11 & 17 \\
\hline & & gender \% & $20.7 \%$ & $31.4 \%$ & $26.6 \%$ \\
\hline & \multirow[t]{2}{*}{4 to 6 diseases } & count & 1 & 8 & 9 \\
\hline & & gender $\%$ & $3.4 \%$ & $22.9 \%$ & $14.1 \%$ \\
\hline & \multirow{2}{*}{$\begin{array}{l}\text { greater than } 6 \\
\text { diseases }\end{array}$} & count & 1 & 5 & 6 \\
\hline & & gender $\%$ & $3.4 \%$ & $14.3 \%$ & $9.4 \%$ \\
\hline \multirow{8}{*}{$\begin{array}{l}\text { Number of self-reported } \\
\text { drugs taken } \\
p<0.001\end{array}$} & \multirow[t]{2}{*}{ up to 2 drugs } & count & 8 & 1 & 9 \\
\hline & & gender \% & $27.6 \%$ & $2.9 \%$ & $14.1 \%$ \\
\hline & \multirow[t]{2}{*}{3 to 4 drugs } & count & 9 & 6 & 15 \\
\hline & & gender $\%$ & $31.0 \%$ & $17.1 \%$ & $23.4 \%$ \\
\hline & \multirow[t]{2}{*}{4 to 6 drugs } & count & 6 & 12 & 18 \\
\hline & & gender \% & $20.7 \%$ & $34.3 \%$ & $28.1 \%$ \\
\hline & \multirow[t]{2}{*}{ greater than 6 drugs } & count & 6 & 16 & 22 \\
\hline & & gender $\%$ & $20.7 \%$ & $45.7 \%$ & $34.4 \%$ \\
\hline \multirow{8}{*}{$\begin{array}{l}\text { Self-reported years of } \\
\text { education } \\
p<0.001\end{array}$} & \multirow[t]{2}{*}{ less than 4 years } & count & 4 & 19 & 23 \\
\hline & & gender $\%$ & $13.8 \%$ & $54.3 \%$ & $35.9 \%$ \\
\hline & \multirow[t]{2}{*}{4 years } & count & 20 & 14 & 34 \\
\hline & & gender $\%$ & $69.0 \%$ & $40.0 \%$ & $53.1 \%$ \\
\hline & \multirow[t]{2}{*}{7 years } & count & 5 & 1 & 6 \\
\hline & & gender $\%$ & $17.2 \%$ & $2.9 \%$ & $9.4 \%$ \\
\hline & \multirow[t]{2}{*}{ greater than 7 years } & count & 0 & 1 & 1 \\
\hline & & gender $\%$ & $0.0 \%$ & $2.9 \%$ & $1.6 \%$ \\
\hline \multirow{2}{*}{\multicolumn{2}{|c|}{ Total }} & count & 29 & 35 & 64 \\
\hline & & gender \% & $100.0 \%$ & $100.0 \%$ & $100.0 \%$ \\
\hline
\end{tabular}

Table 4 shows the assessment of internal consistency and the strength of the relationship between the results obtained in the two different moments. Cronbach's alpha coefficient presented a test value of 0.420 and a re-test value of 0.409 , and Spearman's Rank Order Correlation (rho) presented a test value of 1.000 and a re-test value of 0.969 .

Table 5 shows the assessment of internal consistency for each item applied in the two different moments, based on
Cronbach's alpha coefficient, scale mean and variation and corrected item total correlation. All items had 64 answers, except for items 1 and 3, which had 63 answers. Item 6 had the lowest scale mean in the test and the re-test (1.0938 and 1.1094, respectively). Item 7 had the highest mean in the test and the re-test (1.6563 and 1.6406, respectively). Items 1,3 and 5 had the lowest difference in the scale variation between test and re-test. Item 6 had the highest difference in the scale variation 
in the test and re-test. Cronbach's alpha coefficient varied between 1.000 and 0.906 (items 1 and 4, respectively).

Perceptibility by the Flesher instrument was 75.11 , meaning the scale was relatively easy to understand.

For the study's third phase, Table 6 shows the socio-demographic characteristics of the purposive sample. We found no differences by gender for the studied variables.

Table 7 shows Katz and PRISMA-7 statistics, class "independence" being the most frequent $(n=75,59.1 \%)$ for the Katz Index. For PRISMA-7, 46 (36.2\%) of the respondents had three or more positive answers.

Table 8 shows the distribution of the results on the Katz scale according to the three affirmative answer cut-off on the
PRISMA-7 frailty scale. We found a statistically significant association between the level of dependence and the diagnosis of frailty $(p<0.001)$. We also found a Spearman's correlation of $\rho=$ $0.477(p<0.001)$ between the total of the two scales.

Table 9 shows PRISMA-7 classes and socio-demographic statistics for the study's third phase. There were more individuals with less than three affirmative answers $(81,63.8 \%)$. In the group of frail individuals (three or more affirmative answers on the PRISMA-7 scale), we found more women $(54.3 \%, \mathrm{~ns})$, more people from the oldest age group $(52.2 \%, p<0.001)$, more selfreported multimorbidity, with four or more diseases $(34.8 \%, \mathrm{~ns})$, more self-reported medicines, taking 4 or more drugs $(73.9 \%$, $n s)$, and less education, 4 or less years $(86.9 \%, n s)$.

Table 4. Test and re-test reliability statistics for the study's second phase
\begin{tabular}{|l|l|l|l|l|l|}
\hline Test reliability statistics & Retest reliability statistics & Spearman's rho in test/re-test \\
\hline Cronbach's alpha & Number of items & Cronbach's alpha & Number of items & Test & Re-test \\
\hline 0.420 & 7 & 0.409 & 7 & 1.000 & 0.969 \\
\hline
\end{tabular}

\begin{tabular}{|c|c|c|c|c|c|}
\hline \multirow[t]{2}{*}{ Item } & \multirow{2}{*}{$\begin{array}{l}\text { Scale mean if item } \\
\text { deleted }\end{array}$} & \multirow{2}{*}{$\begin{array}{l}\text { Scale variance if item } \\
\text { deleted }\end{array}$} & \multirow{2}{*}{$\begin{array}{l}\text { Corrected item-total } \\
\text { correlation }\end{array}$} & \multicolumn{2}{|l|}{ Reliability statistics } \\
\hline & & & & Cronbach's alpha & Number of items \\
\hline P1 & 1.5156 & 0.254 & 1.000 & \multirow{2}{*}{1.000} & \multirow{2}{*}{2} \\
\hline P1.1 & 1.5156 & 0.254 & 1.000 & & \\
\hline P2 & 1.3906 & 0.242 & 0.937 & \multirow{2}{*}{0.968} & \multirow{2}{*}{2} \\
\hline P2.1 & 1.4219 & 0.248 & 0.937 & & \\
\hline P3 & 1.2698 & 0.200 & 0.919 & \multirow{2}{*}{0.958} & \multirow{2}{*}{2} \\
\hline P3.1 & 1.2698 & 0.200 & 0.919 & & \\
\hline P4 & 1.4531 & 0.252 & 0.906 & \multirow{2}{*}{0.951} & \multirow{2}{*}{2} \\
\hline P4.1 & 1.4688 & 0.253 & 0.906 & & \\
\hline P5 & 1.5000 & 0.254 & 0.969 & \multirow{2}{*}{0.984} & \multirow{2}{*}{2} \\
\hline P5.1 & 1.4844 & 0.254 & 0.969 & & \\
\hline P6 & 1.0938 & 0.086 & 0.918 & \multirow{2}{*}{0.956} & \multirow{2}{*}{2} \\
\hline P6.1 & 1.1094 & 0.099 & 0.918 & & \\
\hline P7 & 1.6563 & 0.229 & 0.966 & \multirow{2}{*}{0.983} & \multirow{2}{*}{2} \\
\hline P7.1 & 1.6406 & 0.234 & 0.966 & & \\
\hline
\end{tabular}

Table 6. Socio-demographic statistics for the study's third phase

\begin{tabular}{|c|c|c|c|c|c|}
\hline & & & \multicolumn{2}{|c|}{ Gender } & \multirow[t]{2}{*}{ Total } \\
\hline & & & male & female & \\
\hline \multirow{6}{*}{$\begin{array}{l}\text { Age } \\
p=0.360\end{array}$} & \multirow[t]{2}{*}{$65-75$ years } & count & 27 & 30 & 57 \\
\hline & & gender \% & $49.1 \%$ & $41.7 \%$ & $44.9 \%$ \\
\hline & \multirow[t]{2}{*}{$76-85$ years } & count & 16 & 22 & 38 \\
\hline & & gender $\%$ & $29.1 \%$ & $30.6 \%$ & $29.9 \%$ \\
\hline & \multirow{2}{*}{$\begin{array}{l}\text { equal or greater than } 86 \\
\text { years }\end{array}$} & count & 12 & 20 & 32 \\
\hline & & gender \% & $21.8 \%$ & $27.8 \%$ & $25.2 \%$ \\
\hline \multirow{8}{*}{$\begin{array}{l}\text { Number of self-reported } \\
\text { diseases } \\
p=0.192\end{array}$} & \multirow[t]{2}{*}{ up to 2 diseases } & count & 24 & 24 & 48 \\
\hline & & gender $\%$ & $43.6 \%$ & $33.3 \%$ & $37.8 \%$ \\
\hline & \multirow[t]{2}{*}{3 to 4 diseases } & count & 19 & 25 & 44 \\
\hline & & gender $\%$ & $34.5 \%$ & $34.7 \%$ & $34.6 \%$ \\
\hline & \multirow[t]{2}{*}{4 to 6 diseases } & count & 6 & 15 & 21 \\
\hline & & gender \% & $10.9 \%$ & $20.8 \%$ & $16.5 \%$ \\
\hline & \multirow[t]{2}{*}{ greater than 6 diseases } & count & 6 & 8 & 14 \\
\hline & & gender \% & $10.9 \%$ & $11.1 \%$ & $11.0 \%$ \\
\hline
\end{tabular}




\begin{tabular}{|c|c|c|c|c|c|}
\hline & & & \multicolumn{2}{|l|}{ Gender } & \multirow[t]{2}{*}{ Total } \\
\hline & & & male & female & \\
\hline \multirow{8}{*}{$\begin{array}{l}\text { Number of self-reported } \\
\text { drugs taken } \\
p=0.946\end{array}$} & \multirow[t]{2}{*}{ up to 2 drugs } & count & 10 & 12 & 22 \\
\hline & & gender \% & $18.2 \%$ & $16.7 \%$ & $17.3 \%$ \\
\hline & \multirow[t]{2}{*}{3 to 4 drugs } & count & 13 & 15 & 28 \\
\hline & & gender \% & $23.6 \%$ & $20.8 \%$ & $22.0 \%$ \\
\hline & \multirow[t]{2}{*}{4 to 6 drugs } & count & 14 & 24 & 38 \\
\hline & & gender \% & $25.5 \%$ & $33.3 \%$ & $29.9 \%$ \\
\hline & \multirow[t]{2}{*}{ greater than 6 drugs } & count & 18 & 21 & 39 \\
\hline & & gender $\%$ & $32.7 \%$ & $29.2 \%$ & $30.7 \%$ \\
\hline \multirow{8}{*}{$\begin{array}{l}\text { Self-reported years } \\
\text { of education } \\
p=0.004\end{array}$} & \multirow[t]{2}{*}{ less than 4 years } & count & 7 & 31 & 38 \\
\hline & & gender \% & $12.7 \%$ & $43.1 \%$ & $29.9 \%$ \\
\hline & \multirow[t]{2}{*}{4 years } & count & 31 & 26 & 57 \\
\hline & & gender $\%$ & $56.4 \%$ & $36.1 \%$ & $44.9 \%$ \\
\hline & \multirow[t]{2}{*}{7 years } & count & 7 & 2 & 9 \\
\hline & & gender $\%$ & $12.7 \%$ & $2.8 \%$ & $7.1 \%$ \\
\hline & \multirow[t]{2}{*}{ greater than 7 years } & count & 10 & 13 & 23 \\
\hline & & gender \% & $18.2 \%$ & $18.1 \%$ & $18.1 \%$ \\
\hline \multirow{2}{*}{\multicolumn{2}{|c|}{ Total }} & count & 55 & 72 & 127 \\
\hline & & gender $\%$ & $100.0 \%$ & $100.0 \%$ & $100.0 \%$ \\
\hline
\end{tabular}

\begin{tabular}{|l|l|l|}
\hline Table 7. Katz statistics for the study's third phase & Frequency & Valid percentage \\
\hline Katz classes & 5 & $3.9 \%$ \\
\hline Total dependence & 4 & $3.1 \%$ \\
\hline Severe dependence & 12 & $9.4 \%$ \\
\hline Moderate dependence & 31 & $24.4 \%$ \\
\hline Slight dependence & 75 & $59.1 \%$ \\
\hline Independence & & \\
\hline Prisma 7 & 46 & $36.2 \%$ \\
\hline Three or more affirmative answers & & \\
\hline
\end{tabular}

\begin{tabular}{|c|c|c|c|c|c|}
\hline & & & \multicolumn{2}{|l|}{ PRISMA-7* } & \multirow[t]{2}{*}{ Total } \\
\hline & & & $\begin{array}{l}\text { Three or more affirmative } \\
\text { answers }\end{array}$ & $\begin{array}{l}\text { Less than three affirmative } \\
\text { answers }\end{array}$ & \\
\hline \multirow[t]{10}{*}{ Katz } & \multirow[t]{2}{*}{ Total dependence } & count & 5 & 0 & 5 \\
\hline & & percentage & $10.9 \%$ & $0 \%$ & $3.9 \%$ \\
\hline & \multirow[t]{2}{*}{ Severe dependence } & count & 4 & 0 & 4 \\
\hline & & percentage & $8.7 \%$ & $0 \%$ & $3.1 \%$ \\
\hline & \multirow[t]{2}{*}{ Moderate dependence } & count & 8 & 4 & 12 \\
\hline & & percentage & $17.4 \%$ & $4.9 \%$ & $9.4 \%$ \\
\hline & \multirow[t]{2}{*}{ Slight dependence } & count & 16 & 15 & 31 \\
\hline & & percentage & $34.8 \%$ & $18.5 \%$ & $24.4 \%$ \\
\hline & \multirow[t]{2}{*}{ Independence } & count & 13 & 62 & 75 \\
\hline & & percentage & $28.3 \%$ & $76.5 \%$ & $59.1 \%$ \\
\hline \multirow{2}{*}{\multicolumn{2}{|c|}{ Total }} & count & 46 & 81 & 127 \\
\hline & & percentage & $100.0 \%$ & $100.0 \%$ & $100.0 \%$ \\
\hline
\end{tabular}

\footnotetext{
$* p<0.001$.
} 


\begin{tabular}{|c|c|c|c|c|c|}
\hline & & & \multicolumn{2}{|l|}{ PRISMA-7 } & \multirow[t]{2}{*}{ Total } \\
\hline & & & $\begin{array}{l}\text { Three or more affirmative } \\
\text { answers }\end{array}$ & $\begin{array}{l}\text { Less than three affirmative } \\
\text { answers }\end{array}$ & \\
\hline \multirow{4}{*}{$\begin{array}{l}\text { Gender } \\
p=0.414\end{array}$} & \multirow[t]{2}{*}{ male } & count & 21 & 34 & 55 \\
\hline & & percentage & $45.7 \%$ & $42.0 \%$ & $43.3 \%$ \\
\hline & \multirow[t]{2}{*}{ female } & count & 25 & 47 & 72 \\
\hline & & percentage & $54.3 \%$ & $58.0 \%$ & $56.7 \%$ \\
\hline \multirow{6}{*}{$\begin{array}{l}\text { Age } \\
p<0.001\end{array}$} & \multirow[t]{2}{*}{$65-75$ years } & count & 11 & 46 & 57 \\
\hline & & percentage & $23.9 \%$ & $56.8 \%$ & $44.9 \%$ \\
\hline & \multirow[t]{2}{*}{$76-85$ years } & count & 11 & 27 & 38 \\
\hline & & percentage & $23.9 \%$ & $33.3 \%$ & $29.9 \%$ \\
\hline & \multirow{2}{*}{$\begin{array}{l}\text { equal or greater } \\
\text { than } 86 \text { years }\end{array}$} & count & 24 & 8 & 32 \\
\hline & & percentage & $52.2 \%$ & $9.9 \%$ & $25.2 \%$ \\
\hline \multirow{8}{*}{$\begin{array}{l}\text { Number of self- } \\
\text { reported diseases } \\
p=0.258\end{array}$} & \multirow[t]{2}{*}{ up to 2 diseases } & count & 15 & 33 & 48 \\
\hline & & percentage & $32.6 \%$ & $40.7 \%$ & $37.8 \%$ \\
\hline & \multirow[t]{2}{*}{3 to 4 diseases } & count & 15 & 29 & 44 \\
\hline & & percentage & $32.6 \%$ & $35.8 \%$ & $34.6 \%$ \\
\hline & \multirow[t]{2}{*}{4 to 6 diseases } & count & 11 & 10 & 21 \\
\hline & & percentage & $23.9 \%$ & $12.3 \%$ & $16.5 \%$ \\
\hline & \multirow{2}{*}{$\begin{array}{l}\text { greater than } 6 \\
\text { diseases }\end{array}$} & count & 5 & 9 & 14 \\
\hline & & percentage & $10.9 \%$ & $11.1 \%$ & $11.0 \%$ \\
\hline \multirow{8}{*}{$\begin{array}{l}\text { Number of self- } \\
\text { reported } \\
\text { drugs taken } \\
p=0.001\end{array}$} & \multirow[t]{2}{*}{ up to 2 drugs } & count & 3 & 19 & 22 \\
\hline & & percentage & $6.5 \%$ & $23.5 \%$ & $17.3 \%$ \\
\hline & \multirow[t]{2}{*}{3 to 4 drugs } & count & 9 & 19 & 28 \\
\hline & & percentage & $19.6 \%$ & $23.5 \%$ & $22.0 \%$ \\
\hline & \multirow[t]{2}{*}{4 to 6 drugs } & count & 12 & 26 & 38 \\
\hline & & percentage & $26.1 \%$ & $32.1 \%$ & $29.9 \%$ \\
\hline & \multirow[t]{2}{*}{ greater than 6 drugs } & count & 22 & 17 & 39 \\
\hline & & percentage & $47.8 \%$ & $21.0 \%$ & $30.7 \%$ \\
\hline \multirow{8}{*}{$\begin{array}{l}\text { Self-reported years } \\
\text { of education } \\
p=0.001\end{array}$} & \multirow[t]{2}{*}{ less than 4 years } & count & 22 & 16 & 38 \\
\hline & & percentage & $47.8 \%$ & $19.8 \%$ & $29.9 \%$ \\
\hline & \multirow[t]{2}{*}{4 years } & count & 18 & 39 & 57 \\
\hline & & percentage & $39.1 \%$ & $48.1 \%$ & $44.9 \%$ \\
\hline & \multirow[t]{2}{*}{7 years } & count & 2 & 7 & 9 \\
\hline & & percentage & $4.3 \%$ & $8.6 \%$ & $7.1 \%$ \\
\hline & \multirow[t]{2}{*}{ greater than 7 years } & count & 4 & 19 & 23 \\
\hline & & percentage & $8.7 \%$ & $23.5 \%$ & $18.1 \%$ \\
\hline \multirow{2}{*}{\multicolumn{2}{|c|}{ Total }} & count & 46 & 81 & 127 \\
\hline & & percentage & $100.0 \%$ & $100.0 \%$ & $100.0 \%$ \\
\hline
\end{tabular}

\section{Discussion}

According to prior studies for cross-cultural adaptation and validation, the internal consistency assessed by Cronbach's alpha showed a borderline value, probably because of the length of the questionnaire. It should be highlighted that this scale is more of an objective matrix registry than a scale measuring intrinsic variable subjective values about someone's opinion on a subject.

In the evaluation of the internal consistency of the test, Seanger et al. [29] obtained a Cronbach's alpha coefficient value of 0.619 , which is higher than that obtained in this study (Cronbach's alpha coefficient of 0.420 ). This difference may be due to differences in sample size and intrinsic characteristics. The study of Seanger et al. [29] does not present the value of the Cronbach's alpha coefficient for the re-test.
This is a valid European Portuguese version of the PRISMA-7 scale, which is easy to understand.

In the second phase of the study, the Cronbach's alpha coefficient denotes internal consistency and reliability, and the Spearman's Rank Order Correlation indicates a positive association between the results obtained in the test and re-test of the translation of the PRISMA-7 scale.

In the third phase of the study, most of the older people interviewed were aged between 65 and 75 years and had 4 years or less of education. The high number of self-reported drugs taken daily reflected the health status of older people that access primary health care services.

The identification of frail older people with the PRISMA-7 scale was, significantly, in accordance with the classification of functionality of the Katz scale, since, for dependency classifica- 
tions on the Katz scale, there was a higher number of individuals with three or more affirmative answers on the PRISMA-7 scale, and simultaneously, for the independence classification on Katz scale, there was a higher number of individuals with less than three affirmative answers on the PRISMA-7 scale.

In both genders, there were similar percentages of three or more affirmative responses, indicating that the PRISMA-7 scale allows for the identification of frail older people regardless of gender.

The PRISMA-7 scale was sensitive to the socio-demographic factors: an increase in age and in the number of self-reported drugs taken daily was associated with an increase in the number of individuals with three or more affirmative answers; a decrease in the number of self-reported diseases was associated with a decrease in the number of individuals with three or more affirmative answers; and an increase in the number of years of education was associated with a decrease in the number of individuals with 3 or more affirmative answers.

As in the study of Seanger et al. [29], the sample of this study had a diversity of socio-demographic characteristics, allowing for the evaluation of its applicability in different age groups.

For the PRISMA-7 class of three or more affirmative answers, Seanger et al. [29] obtained a higher percentage of individuals in the age group of 60 to 74 years, while in the present study, the age group with the highest percentage was equal or higher than the age group of 86 years. This may be due to differences in cultural characteristics and the time lapse between the two studies. For educational level and gender, both papers present a higher percentage of individuals of the female gender and in the group with less than 4 years of education. These results are in accordance with the risk of greater frailty in these groups.
The results indicate that the PRISMA-7 scale has the sensitivity to detect people between the ages of 65 and 85 at risk of frailty, and thus it can be used to identify people at risk of frailty early in this age group, widening the target population for which it is intended. In this way, it will allow the timely implementation of health services with the aim of preventing the emergence of fragility syndrome, contributing to the improvement of quality of life and increased independence, which will consequently contribute to the reduction of consumption and expenditures of health services.

The PRISMA-7 scale, being specific for the identification of fragility syndrome, may be an important tool for the follow-up, prognosis and evaluation of the effectiveness of the treatments provided.

In the presence of fragility syndrome, it would be pertinent to verify if the PRISMA-7 scale would also be a useful tool to evaluate caregivers' perceptions of a person's frailty. Knowledge of caregivers' perceptions could contribute to early identification of the need for community service support.

\section{Conclusions}

The PRISMA-7 scale has been adapted and validated to the European spoken Portuguese language. The results of this study suggest the adequacy of the validation process and the effectiveness in early identification of frail older patients. The PRISMA-7 version for European Portuguese is a simple, easy to apply and reliable tool for discovering and implementing preventive and rehabilitation health services for frail older people. Therefore, it is recommended as a tool to identify frail older people in the community.

Source of funding: This work was funded from the authors' own resources.

Conflicts of interest: The authors declare no conflicts of interest.

\section{References}

1. Bieniek J, Wilczyński K, Szewieczek J. Fried frailty phenotype assessment components as applied to geriatric inpatients. Clin Interv Ageing 2016; 11: 453-459, doi: 10.2147/CIA.S101369.

2. Bone $A E$, Morgan $M$, Maddocks $M$, et al. Developing a model of short-term integrated palliative and supportive care for frail older people in community settings: perspectives of older people, carers and other key stakeholders. Age Ageing 2016; 45(6): 863-873, doi: 10.1093/ageing/afw124.

3. Bowman C, Meyer J. Formative care: defining the purpose and clinical practice of care for the frail. J R Soc Med 2014; 107(3): 95-98, doi: 10.1177/0141076813512298.

4. Khezrian M, Myint PK, McNeil C, et al. A review of frailty syndrome and its physical, cognitive and emotional domains in the older people. Geriatrics 2017; 2(4): 36, doi: 10.3390/geriatrics2040036.

5. Mazya AL, Garvin P, Ekdahl AW. Outpatient comprehensive geriatric assessment: effects on frailty and mortality in old people with multimorbidity and high health care utilization. Ageing Clin Exp Res 2019; 31(4): 519-525, doi: 10.1007/s40520-018-1004-z.

6. Muntinga ME, Van Leeuwen KM, Schellevis FG, et al. From concept to content: assessing the implementation fidelity of a chronic care model for frail, older people who live at home. BMC Health Serv Res 2015; 15: 18, doi: 10.1186/s12913-014-0662-6.

7. Comans TA, Peel NM, Hubbard RE, et al. The increase in healthcare costs associated with frailty in older people discharged to a post acute transition care program. Age Ageing 2016; 45(2): 317-320, doi: 10.1093/ageing/afv196.

8. Ekerstad N, Karlson BW, Ivanoff SD, et al. Is the acute care of frail older people patients in a comprehensive geriatric assessment unit superior to conventional acute medical care? Clin Interv Ageing 2017; 12: 1-9, doi: 10.2147/CIA.S124003.

9. Lim WS, Wong SF, Leong I, et al. Forging a frailty-ready healthcare system to meet population ageing. Int J Environ Res Public Health 2017; 14: 1448, doi: 10.3390/ijerph14121448.

10. Yang F, Gu D. Predictability of frailty index and its components on mortality in older adults in china. BMC Geriatr 2016; 16: 145, doi: 10.1186/s12877-016-0317-z.

11. Yeolekar ME, Sukumaran S. Frailty syndrome: a review. J Assoc Physicians India 2014; 62: 34-38.

12. Aarts S, Patel KV, Garcia ME, et al. Co-presence of multimorbidity and disability with frailty: an examination of heterogeneity in the frail older population. J Frailty Ageing 2015; 4(3): 131-138, doi: 10.14283/jfa.2015.45.

13. Chen X, Mao G, Leng SX. Frailty syndrome: an overview. Clin Interv Ageing 2014; 9: 433-441, doi: 10.2147/CIA.S45300.

14. Grden CRB, Lenardt MH, Sousa JAV, et al. Associations between frailty syndrome and sociodemographic characteristics in long-lived individuals of a community. Rev Lat Am Enfermagem 2017; 25: e2886, doi: 10.1590/1518-8345.1770.2886.

15. Lourenço RA. [Fragility syndrome in the older people: clinical and biological markers]. Revista HUPE 2008; 7(1): $21-29$ (in Portuguese).

16. Sousa-Santos AR, Afonso C, Moreira P, et al. Weakness: the most frequent criterion among pre-frail and frail older Portuguese. Arch Gerontol Geriatr 2018; 74: 162-168, doi: 10.1016/j.archger.2017.10.018. 
17. Wen YC, Chen LK, Hsiao FY. Predicting mortality and hospitalization of older adults by the multimorbidity frailty index. PLOS ONE 2017; 12(11): e0187825, doi: 10.1371/journal.pone.0187825.

18. Pritchard JM, Kennedy CC, Karampatos S, et al. Measuring frailty in clinical practice: a comparison of physical frailty assessment methods in a geriatric out-patient clinic. BMC Geriatr 2017; 17(1): 264, doi: 10.1186/s12877-017-0623-0.

19. Brouwers $\mathrm{C}$, Merten $\mathrm{H}$, Willems $\mathrm{M}$, et al. Improving care for older patients in the acute setting: a qualitative study with healthcare providers. Neth J Med 2017; 75(8): 335-344.

20. Buta BJ, Walston JD, Godino JG, et al. Frailty assessment instruments: systematic characterization of the uses and contexts of highlycited instruments. Ageing Res Rev 2016; 26: 53-61, doi: 10.1016/j.arr.2015.12.003.

21. Ekerstad N, Ivanoff SD, Landahl S, et al. Acute care of severely frail older people patients in a CGA-unit is associated with less functional decline than conventional acute care. Clin Interv Ageing 2017; 12: 1239-1249, doi: 10.2147/CIA.S139230.

22. Fried LP, Tangen CM, Walstom J, et al. Frailty in older adults: evidence for phenotype. J Gerontol A Biol Sci Med Sci 2001; 56(3): M146- M156, doi: 10.1093/gerona/56.3.m146.

23. Hanlon $\mathrm{P}$, Nicholl $\mathrm{BI}$, Jani $\mathrm{BD}$, et al. Frailty and pre-frailty in middle-aged and older adults and its association with multimorbidity and mortality: a prospective analysis of 493737 UK biobank participants. Lancet Public Health 2018; 3(7): e323-e332, doi: 10.1016/S24682667(18)30091-4.

24. Lana LD, Schneider RH. [The frailty syndrome in older people: a narrative review]. Rev Bras Geriatr Gerontol 2014; 17(3): 673-680, doi: 10.1590/1809-9823.2014.12162 (in Portuguese).

25. Schoenborn NL, Rasmussen SEVP, Xue QL, et al. Older adults' perceptions and informational needs regarding frailty. BMC Geriatr 2018; 18: 46, doi: 10.1186/s12877-018-0741-3.

26. Münzer T. Medical challenges at the end of the first ten decades of life. Swiss Med Wkly 2017; 147: w14461, doi: 10.4414/ smw.2017.14461.

27. Duarte M, Paúl C. Prevalence of phenotypic frailty during the ageing process in a Portuguese community. Rev Bras Geriatr Gerontol 2015; 18(4): 871-880, doi: 10.1590/1809-9823.2015.14160.

28. Arik G, Varan HD, Yavuz BB, et al. Validation of Katz index of independence in activities of daily living in Turkish older adults. Arch Gerontol Geriatr 2015; 61(3): 344-350, doi: 10.1016/j.archger.2015.08.019.

29. Saenger ALF, Caldas CP, Raîche M, et al. Identifying the loss of functional independence of older people residing in the community: Validation of the PRISMA-7 instrument in Brazil. Arch Gerontol Geriatr 2018; 74: 62-67, doi: 10.1016/j.archger.2017.09.008.

30. Hébert R, Durand PJ, Dubuc N, et al. Frail older people patients, new model for integrated service delivery. Can Fam Physician 2003; 49: 992-997.

31. Saenger ALF, Caldas CP, Mota LB. [Cross-cultural adaptation of the PRISMA-7 instrument for use in Brazil: evaluation of conceptual, item, and semantic equivalences]. Cad Saúde Publica 2016; 32(9): e00072015, doi: 10.1590/0102-311X00072015 (in Portuguese).

32. Duarte YAO, Andrade CL, Lebrão ML. [Katz Index on older people functionality evaluation]. Rev Esc Enferm USP 2007; 42(2): 317-325, doi: 10.1590/S0080-62342007000200021 (in Portuguese).

33. Pallant J. SPSS Survival Manual: a step by step guide to data analysis using SPSS. Philadelphia: Open University Press; 2005.

Tables: 9

Figures: 0

References: 33

Received: 23.06.2019

Reviewed: 27.06.2019

Accepted: 12.09 .2019

Address for correspondence:

Luiz Miguel Santiago, MD, PhD, Assoc. Prof.

Faculdade de Medicina da Universidade de Coimbra

Azinhaga de Santa Comba (Celas)

3000-548 Coimbra

Portugal

Tel.: +351966225773

E-mail: luizmiguel.santiago@gmail.com 